1, 3- Di met hyl - 2- (3- ni tro- 1, 2, 4 tri azol - 1-yl ) - 2pyrrol i di n-1-yl-1, 3, 2- di azaphosphol i di ni um hexaf I uor ophosphate (MNT): a powerful condensing reagent for phosphate and phosphonat e esters

\begin{tabular}{|l|l|}
\hline 著者 & $\begin{array}{l}\text { Oka Nat suhi sa, Shi mi zu Nanor u, Sai go Kazuhi ko, } \\
\text { Wada Takeshi }\end{array}$ \\
\hline $\begin{array}{l}\text { j our nal or } \\
\text { publ i cat i on t i tl e }\end{array}$ & Tet r ahedr on \\
\hline vol une & 62 \\
\hline nunber & 15 \\
\hline page r ange & $3667-3673$ \\
\hline year & $2006-04-10$ \\
\hline URL & ht t p: $/ /$ hdl . handl e. net $/ 10173 / 726$ \\
\hline
\end{tabular}




\section{Graphical Abstract}

1,3-Dimethyl-2-(3-nitro-1,2,4-triazol-1-yl)-2-pyrrolidin-1-yl-1,3,2-diazaphospholidinium hexafluorophosphate: a powerful condensing reagent for phosphate and phosphonate esters

Natsuhisa Oka, Mamoru Shimizu, Kazuhiko Saigo, and Takeshi Wada*
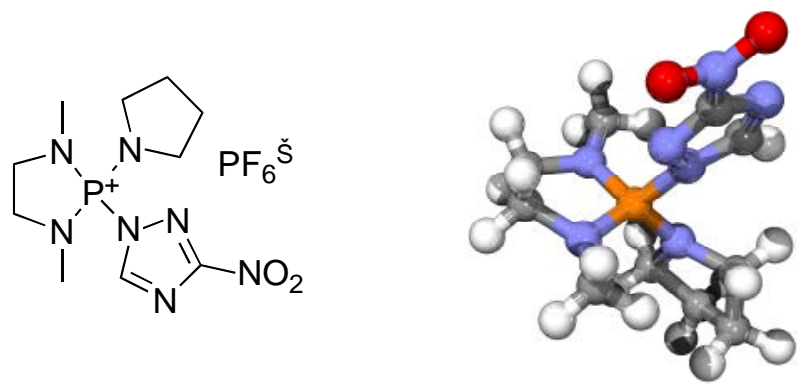


\title{
1,3-Dimethyl-2-(3-nitro-1,2,4-triazol-1-yl)-2-pyrrolidin-1-yl-1,3,2-diazaphospholidinium hexafluorophosphate (MNTP): a powerful condensing reagent for phosphate and phosphonate esters
}

\author{
Natsuhisa Oka, Mamoru Shimizu, Kazuhiko Saigo, and Takeshi Wada* \\ Department of Medical Genome Sciences, Graduate School of Frontier Sciences, \\ The University of Tokyo, Kashiwanoha, Kashiwa, Chiba 277-8562, Japan
}

\begin{abstract}
A

novel

phosphonium-type

condensing

reagent,

1,3-dimethyl-2-(3-nitro-1,2,4-triazol-1-yl)-2-pyrrolidin-1-yl-1,3,2-diazaphospholidinium hexafluorophosphate (MNTP), was designed and synthesized. A ${ }^{31} \mathrm{P}$ NMR study on the condensation reactions of phosphate, alkylphosphonate, boranophosphate, and $H$-phosphonate derivatives with an alcohol in the presence of MNTP demonstrated the versatility and the enhanced activity of the new condensing reagent, compared to the previously reported phosphonium-type condensing reagents. The mechanism of the condensation reactions mediated by MNTP is discussed on the basis of the ${ }^{31} \mathrm{P}$ NMR studies and theoretical calculations.
\end{abstract}

\section{Key words}

Phosphonium-type condensing reagent, Phosphate, Alkylphosphonate, Boranophosphate, $H$-phosphonate

\section{Introduction}

Phosphate esters, especially those which play important roles in cells such as nucleic acids, ${ }^{1,2}$ phosphoinositols, ${ }^{3,4}$ phospholipids, ${ }^{5}$ sugar phosphates, ${ }^{5,6}$ and phosphopeptides, ${ }^{7}$ are one class of important targets in current synthetic organic chemistry. The most frequently 
used method to synthesize these phosphate esters as well as their analogs is the $O$-phosphitylation with phosphoramidites (the phosphoramidite method), ${ }^{8-11}$ because the reactions proceed rapidly and efficiently under mild acidic conditions. However, this method has some shortcomings. Firstly, care should be taken to store the phosphitylating reagents due to their instability to oxidation and hydrolysis. The reactions have to be carried out under strictly anhydrous conditions for the same reason. Secondly, an additional step, such as oxidation, sulfurization, or boronation, to transform the phosphite intermediates into the corresponding phosphate derivatives is required, which may cause some undesired side reactions depending on substrates (e.g., the dealkylation by $\mathrm{I}^{-}$and/or hydrolysis of substrates during oxidation with $\mathrm{I}_{2} / \mathrm{H}_{2} \mathrm{O}$, the reduction of substrates caused by a boronating reagent, and so on). ${ }^{12-16}$

In the course of our study to develop new synthetic methods for nucleic acid derivatives, we have been devoting much effort to the design and synthesis of condensing reagents for $O$-phosphorylations and $O$-phosphonylations, which have some advantages over the $O$-phosphitylations by the phosphoramidite method and can be appropriately chosen depending on target molecules. ${ }^{17-19}$ The advantages are: 1) condensation reactions can be carried out without strictly anhydrous conditions; 2) the phosphorylating and phosphonylating reagents can be stored for a long period of time without being oxidized or hydrolyzed; 3) an additional step, such as oxidation, is eliminated. These characteristics would enable one to synthesize some functionalized molecules, which are difficult to be synthesized by the phosphoramidite method. As such a successful result, we have developed a new boranophosphorylation reaction of nucleosides mediated by a condensing reagent and could synthesize dinucleoside boranophosphates containing four nucleobases, ${ }^{18,19}$ which were difficult to be synthesized by the phosphoramidite method due to serious side reactions on the nucleobases caused by a boronating reagent during the boronation of the phosphite intermediates. $^{13-16}$ However, $O$-phosphorylations and $O$-phosphonylations (except for the 
reaction of reactive $H$-phosphonates) suffer from the low reactivity of the phosphorylating and phosphonylating reagents, compared to that of phosphitylating reagents in the phosphoramidite method. This would be a significant drawback, especially when target molecules require multiple phosphorylations or phosphonylations as the synthesis of DNA/RNA analogs. To remedy this drawback and to develop an efficient condensing reagent applicable to a wide variety of phosphate derivatives, we designed a new phosphonium-type condensing reagent, 1,3-dimethyl-2-(3-nitro-1,2,4-triazol-1-yl)-2-pyrrolidin-1-yl-1,3,2-diazaphospholidinium hexafluorophosphate (1). In this paper, we report the synthesis of $\mathbf{1}$ and its application to the synthesis of phosphate and phosphonate esters. The synthesis of $\mathbf{1}$ and the comparison of the reactivity of $\mathbf{1}$ with that of the prototype condensing reagent, 3-nitro-1,2,4-triazol-1-yl-tris(pyrrolidin-1-yl)phosphonium hexafluorophosphate (2), ${ }^{19}$ are also described in detail.

\section{Results and discussion}

2.1.

Design

and

synthesis

of

1,3-dimethyl-2-(3-nitro-1,2,4-triazol-1-yl)-2-pyrrolidin-1-yl-1,3,2-diazaphospholidinium hexafluorophosphate (MNTP) and 3-nitro-1,2,4-triazol-1-yl-tris(pyrrolidin-1-yl)phosphonium hexafluorophosphate (PyNTP)

Phosphonium-type condensing reagents, which were originally developed for the peptide synthesis, ${ }^{20-23}$ have also proven to be effective for the synthesis of phosphate and phosphonate derivatives. $^{17,19,24-27}$ For example,

2-(benzotriazol-1-yloxy)-1,3-dimethyl-2-pyrrolidin-1-yl-1,3,2-diazaphospholidinium hexafluorophosphate (BOMP) (Figure 1, 3) was successfully used for the rapid formation of $H$-phosphonate diesters. ${ }^{17}$ The study showed that $\mathbf{3}$ was much more effective for the 
activation of $H$-phosphonate monoesters than the parent commercially available condensing reagent, benzotriazol-1-yloxy-2-tris(pyrrolidin-1-yl)phosphonium hexafluorophosphate (PyBOP) (Figure 1, 4). ${ }^{21}$ Although 3 is one of the most active condensing reagents at present, we considered that further improvement of the molecular structure would be necessary for the development of a versatile condensing reagent applicable to various phosphate and phosphonate esters. Although the activation of the $\mathrm{P}-\mathrm{O}^{-}$functions of phosphates or phosphonates with 3 would form active intermediates, 1-benzotriazolyl phosphates or phosphonates, they should be much less reactive than activated $H$-phosphonates. Given this situation, we designed 1,3-dimethyl-2-(3-nitro-1,2,4-triazol-1-yl)-2-pyrrolidin-1-yl-1,3,2-diazaphospholidinium hexafluorophosphate (MNTP, 1), in which 3-nitro-1,2,4-triazole was introduced in the place of 1-hydroxybenzotriazole in $\mathbf{3}$, as a new condensing reagent, because the effectiveness of 3-nitro-1,2,4-triazole as a nucleophilic catalyst has already been demonstrated with the prototype condensing reagent, 3-nitro-1,2,4-triazol-1-yl-tris(pyrrolidin-1-yl)phosphonium hexafluorophosphate (PyNTP, 2), ${ }^{19}$ and because 3-nitro-1,2,4-trialzole has also been used as an efficient nucleophilic catalyst for $O$-phosphorylations and $O$-phosphonylations with conventional condensing reagents, such as 1-(mesitylenesulfonyl)-3-nitro-1,2,4-triazole $(\mathrm{MSNT}){ }^{28}$

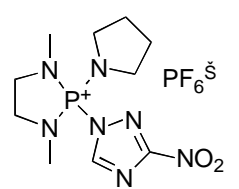

1

NMTP

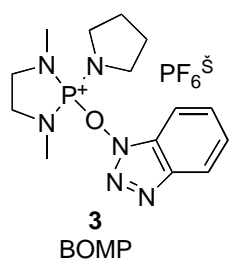

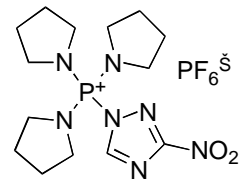

2

PyNTP

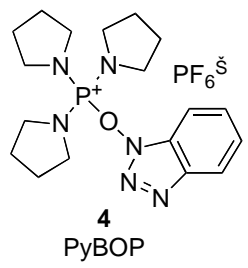

Figure 1. Phosphonium-type condensing reagents. 
The synthesis of $\mathbf{1}$ is outlined in 1 Scheme 1,3-Dimethyl-2-pyrrolidin-1-yl-1,3,2-diazaphospholidine (8) was prepared from $N, N^{\prime}$-dimethyl-1,2-ethylenediamine (5) in 3 steps, $^{29}$ and 8 was allowed to react with 3-nitro-1,2,4-triazole in the presence of carbon tetrachloride, followed by a counteranion exchange to give $\mathbf{1}$ as a colorless crystalline solid, which could be stored in a vial for at least 12 months at $-30{ }^{\circ} \mathrm{C}$.

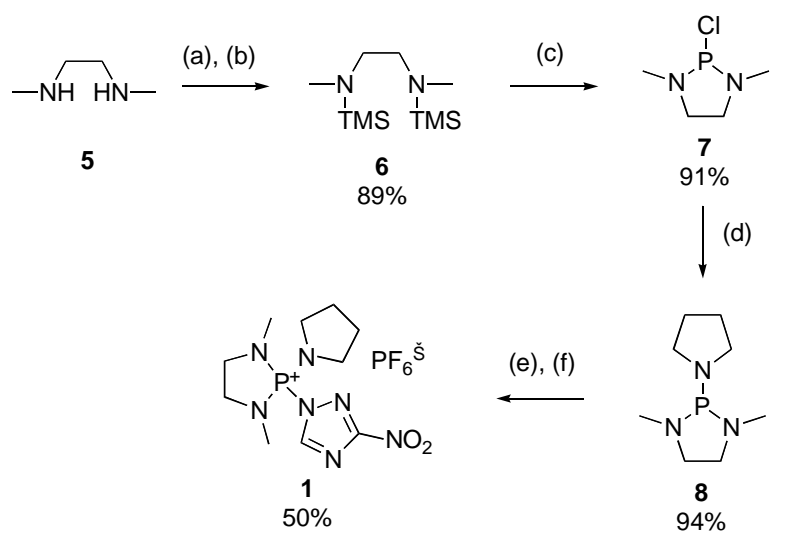

Scheme 1. Synthesis of MNTP 1. Reagents and conditions: (a) BuLi (2.1 equiv), $\mathrm{Et}_{2} \mathrm{O}$-hexane, $-78{ }^{\circ} \mathrm{C}$ then $0{ }^{\circ} \mathrm{C}, 30 \mathrm{~min}$; (b) $\mathrm{TMSCl}$ (2.1 equiv), $-78{ }^{\circ} \mathrm{C}$ then $\mathrm{rt}, 2 \mathrm{~h}$; (c) $\mathrm{PCl}_{3}(1$ equiv), $0{ }^{\circ} \mathrm{C}$ then $\mathrm{rt}, 6 \mathrm{~h}$; (d) 1-(trimethylsilyl)pyrrolidine (1 equiv), $0{ }^{\circ} \mathrm{C}$ then reflux, $1 \mathrm{~h}$; (e) 3-nitro-1,2,4-triazole (1 equiv), $\mathrm{CCl}_{4}$ (4 equiv), $\mathrm{CH}_{2} \mathrm{Cl}_{2},-78{ }^{\circ} \mathrm{C}, 1 \mathrm{~h}$ then $\mathrm{rt}, 30 \mathrm{~min}$; (f) $\mathrm{KPF}_{6}$ (1 equiv), $\mathrm{CH}_{3} \mathrm{CN}, \mathrm{rt}, 1 \mathrm{~h}$.

PyNTP 2 could be synthesized by a much simpler protocol than that for $\mathbf{1}$ (Scheme 2). The nucleophilic substitution of the chloro group on the phosphorus atom of a commercially available condensing reagent, chlorotri(pyrrolidin-1-yl)phosphonium hexafluorophosphate (PyCloP, 9) $)^{22}$ with 3-nitro-1,2,4-triazole in the presence of $\mathrm{NaH}$ yielded $\mathbf{2}$ in good yield as a colorless crystalline solid, which could also be stored in a vial for at least 12 months at -30 ${ }^{\circ} \mathrm{C}$. 


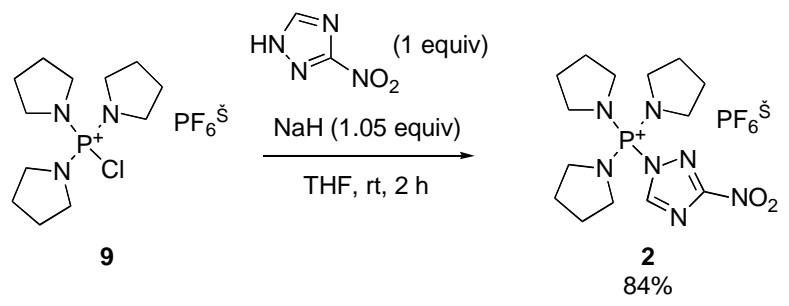

Scheme 2. Synthesis of PyNTP 2.

The optimized geometries of $\mathbf{1}$ and $\mathbf{2}$ calculated at the HF/6-31G* level showed that $\mathbf{1}$ was a little less congested around the phosphorus atom, compared to 2 (Figure 2). This reduced steric hindrance of $\mathbf{1}$ may have some positive effect on the reaction rate mediated by this new condensing reagent.

1

2

Figure 2. Optimized geometries of 1 and 2 calculated at the HF/6-31G* level.

\subsection{Condensation reactions of dimethyl phosphate in the presence of the phosphonium-type condensing reagents 1 and 2}

For the validation of our molecular design of the new phosphonium-type condensing reagent, we chose the condensation of dimethyl phosphate 10a with 2-phenylethanol 11 as a simple model reaction, and compared the condensation activity of $\mathbf{1}$ with that of $\mathbf{2}$ and $\mathbf{3}$. The phosphate 10a was allowed to condense with $\mathbf{1 1}$ (1.5 equiv) in the presence of $\mathbf{1}, \mathbf{2}$ or $\mathbf{3}$ (3 equiv) and a weak, less nucleophilic base, 2,6-lutidine (10 equiv), as an acid scavenger in $\mathrm{CH}_{3} \mathrm{CN}-\mathrm{CD}_{3} \mathrm{CN}(4: 1, \mathrm{v} / \mathrm{v})$ at $20{ }^{\circ} \mathrm{C}$, and the reactions were monitored by ${ }^{31} \mathrm{P}$ NMR. The results clearly demonstrated the superiority of $\mathbf{1}$ and $\mathbf{2}$ over $\mathbf{3}$ with respect to the reaction rate (Figure 3). Thus, the desired phosphate triester 12a was formed in 98 and $83 \%$ yields after 
150 min when 1 and 2 were used, respectively. In the former case, 12a was isolated in 98\% yield after the usual work-up and purification by silica gel column chromatography. On the other hand, only 33\% of 12a was generated within the same time period, when $\mathbf{3}$ was used.

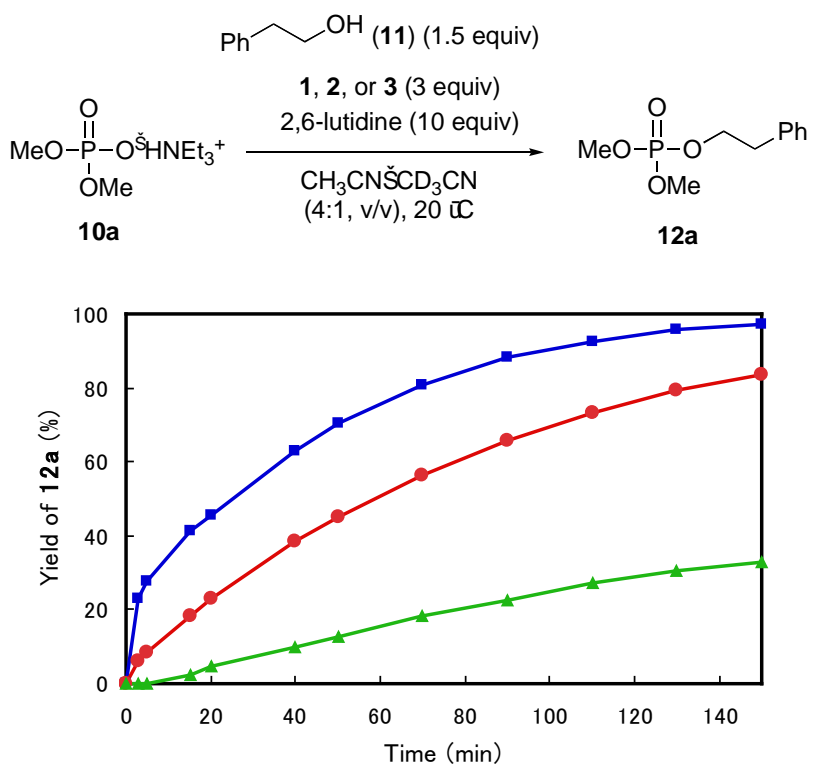

Figure 3. Condensation reactions of dimethyl phosphate 10a with 2-phenylethanol 11 (1.5 equiv) in the presence of $\mathbf{1}, \mathbf{2}$, or 3 (3 equiv) in $\mathrm{CH}_{3} \mathrm{CN}-\mathrm{CD}_{3} \mathrm{CN}(4: 1, \mathrm{v} / \mathrm{v})$ at $20{ }^{\circ} \mathrm{C}$. $\mathbf{m}$, MNTP 1; •, PyNTP 2; $\boldsymbol{\Delta}$, BOMP 3.

The condensation reaction of $\mathbf{1 0 a}$ with $\mathbf{1 1}$ mediated by $\mathbf{1 - 3}$ is most likely to start with the generation of the active intermediate 13a,b (Figure 4). This type of active intermediates have also been proposed for the PyBOP-mediated activation of phosphonates. ${ }^{25}$ There are some possible pathways from 13a,b to the final product 12a. The pathway via the symmetric pyrophosphate 14a (path a) undoubtedly exists; the generation of 14a and its conversion to the final product 12a could be monitored by ${ }^{31} \mathrm{P}$ NMR $\left(\mathbf{1 4 a}, \delta-9.6 ;{ }^{30} \mathbf{1 2 a}, \delta 1.9\right.$, Figure 5$) .{ }^{31}$ In the presence of $\mathbf{1}$ or $\mathbf{2}$, the rate-determining step of the path $a$ must be the reaction of $\mathbf{1 4 a}$ with 3-nitro-1,2,4-triazole $(\mathrm{Nt}-\mathrm{H})$ judging from the fact that 14a was the only intermediate 
observed by ${ }^{31} \mathrm{P}$ NMR. However, there is not only one pathway, because the reaction rate was affected by the phosphonium skeleton of the condensing reagents (Figure 4, 1 vs. 2), which is not involved in the rate-determining step of the path $a$. Our assumption is that there are two other pathways, the paths $b$ and $c$ shown in Figure 4, and the rate constants of the nucleophilic attacks of $\mathrm{X}-\mathrm{H}$ (path $b$ ) and $\mathbf{1 1}$ (path $c$ ) at the electronically neutral phosphorus atom of 13a are larger than at that of $\mathbf{1 3} \mathbf{b}$. Then, we carried out the $a b$ initio molecular orbital calculations (HF/6-31G* level) for 13a,b to find that the energy levels of the unoccupied molecular orbitals (UMOs) of $\mathbf{1 3 a}$ were lower in general than those of $\mathbf{1 3 b} .^{32}$ For example, the energy level of the lowest UMO (LUMO) of 13a was calculated to be $38.7 \mathrm{kcal} / \mathrm{mol}$, whereas that of 13b was $46.3 \mathrm{kcal} / \mathrm{mol}$. The structures of $\mathbf{1}$ and $\mathbf{2}$ may also affect the rate of the nucleophilic attack of 10a at the electronically neutral phosphorus atoms of 13a,b (path $a$ ). However, we consider that the paths $b$ and $c$, which should originally have larger activating energy values than the path $a$, would be relatively more affected than the path $a$.

The slow reaction mediated by $\mathbf{3}$ would be attributed to the less reactive benzotriazol-1-yloxy ester $\mathbf{1 5 b}$ generated from 10a and $3 .^{33}$ In fact, the intermediate $\mathbf{1 5 b}$ was observed throughout the reaction by ${ }^{31} \mathrm{P}$ NMR monitoring $(\delta 1.4)$ and gradually consumed to yield 12a, ${ }^{32}$ whereas the reactive intermediate $\mathbf{1 5 a}$ could not be detected by ${ }^{31} \mathrm{P}$ NMR.

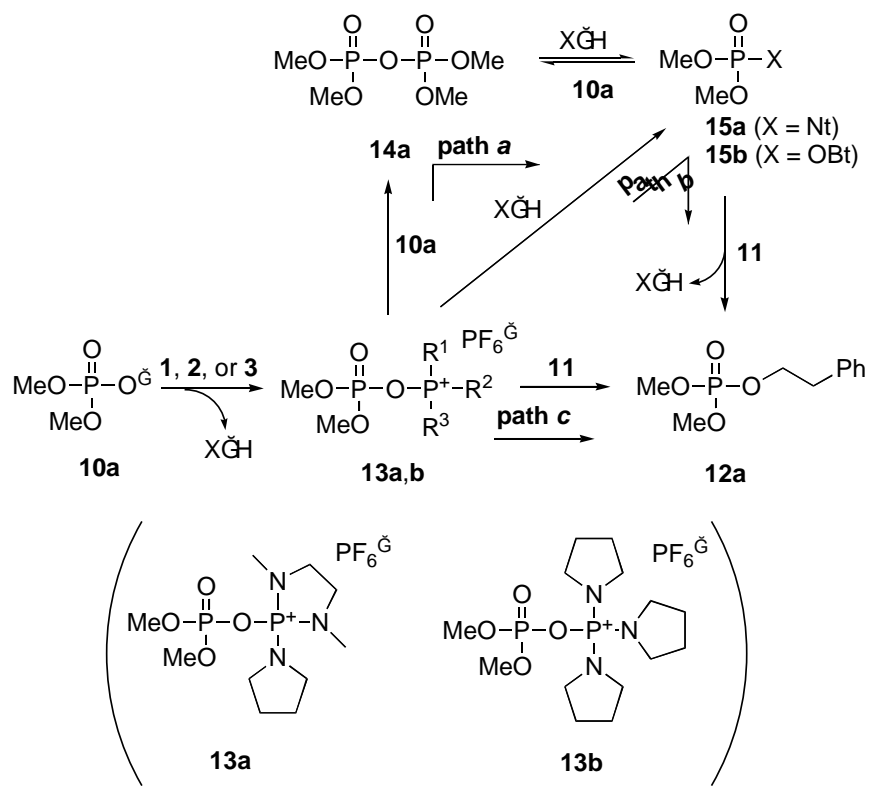


Figure 4. Possible reaction pathways for the reaction of 10a with 11 in the presence of $\mathbf{1}, \mathbf{2}$, or 3. $\mathrm{X}-\mathrm{H}=\mathrm{Nt}-\mathrm{H}=$ 3-nitro-1,2,4-triazole for $\mathbf{1}$ and $2 ; \mathrm{X}-\mathrm{H}=\mathrm{BtO}-\mathrm{H}=$ 1-hydroxybenzotriazole for 3.

It should be noted that there was a by-product when $\mathbf{1}$ was used for the condensation reaction of 10a with 11. A ${ }^{31} \mathrm{P}$ NMR analysis showed a signal at $\delta 34.9$ (Figure 5), which was assigned to that of $\mathbf{1 6}$ by the independent reaction of $\mathbf{1}$ with $\mathbf{1 1}$. This side reaction was rather unexpected, because the nucleophilic attack of alcohols to a positively charged phosphorus atom assisted by a weak base, such as 2,6-lutidine, is known to be slow. ${ }^{17,19,25}$ In fact, this side reaction was not observed when $\mathbf{2}$ or $\mathbf{3}$ was used. ${ }^{34}$ The ratio of $\mathbf{1 6}$ increased upon using a stronger base; the ratios for $\mathbf{1 2 a}$ and 16 upon completely consuming 14a were 45:55 with $N, N, N^{\prime}, N^{\prime}$-tetramethyl-1,8-naphthalenediamine and 48:52 with triethylamine, while 79:21 with 2,6-lutidine. This result suggests that the condensation of less reactive phosphates with sterically less hindered alcohols should be carried out using more than one molar equivalent of the alcohols in the absence of a strong base.

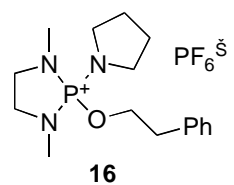




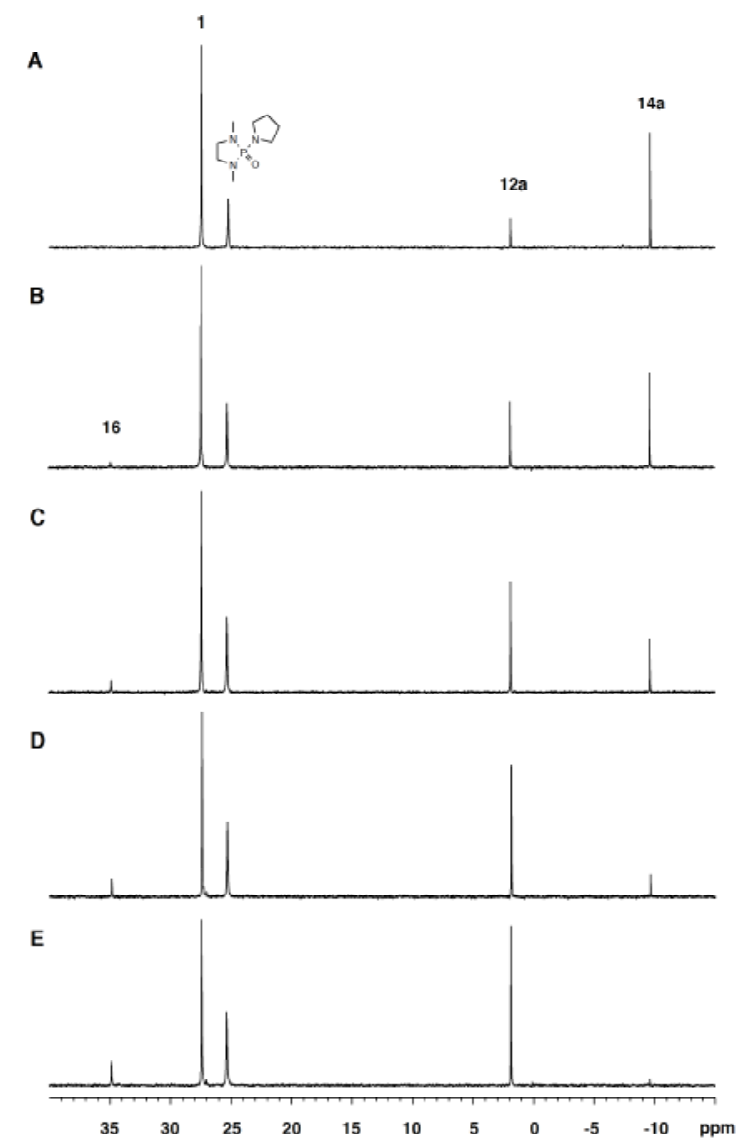

Figure 5. ${ }^{31} \mathrm{P}$ NMR spectra of the reaction mixture obtained by the reaction of $\mathbf{1 0 a}$ with $\mathbf{1 1}$ (1.5 equiv) in the presence of 1 (3 equiv) in $\mathrm{CH}_{3} \mathrm{CN}-\mathrm{CD}_{3} \mathrm{CN}(4: 1, \mathrm{v} / \mathrm{v})$ at $20{ }^{\circ} \mathrm{C}$. (A) $3 \mathrm{~min}$; (B) $20 \mathrm{~min}$; (C) $50 \mathrm{~min}$; (D) $90 \mathrm{~min}$; (E) $150 \mathrm{~min}$.

\subsection{Application of MNTP to various phosphate and phosphonate esters}

In the next stage, the condensation reactions of various phosphate and phosphonate derivatives with 11 were carried out in the presence of $1 .{ }^{31} \mathrm{P}$ NMR monitoring studies demonstrated that $\mathbf{1}$ was more effective for the condensation reactions of $\mathbf{1 0 b}-\mathbf{d}$ with $\mathbf{1 1}$ than for the reaction of $\mathbf{1 0 a}$ with $\mathbf{1 1}$ (Figure 6). Thus, all of the reactions of $\mathbf{1 0 b}-\mathbf{d}$ with $\mathbf{1 1}$ were completed within $40 \mathrm{~min}$; especially 10c and 10d were completely condensed within 3 min and 10 min, respectively. As a result, 12b and 12c were isolated in 99 and $>99 \%$ yields. The quantitative formation of 12d was confirmed by the ${ }^{31} \mathrm{P}$ NMR spectrum, which showed a newly generated signal at $10.6 \mathrm{ppm}$ with a P-H coupling typical of dialkyl $H$-phosphonates 
$\left({ }^{1} \mathrm{~J}_{\mathrm{PH}}=691.3 \mathrm{~Hz}\right) .{ }^{32}$ In the cases of $\mathbf{1 0 b}-\mathbf{d}$, any undesired byproducts including $\mathbf{1 6}$ were not observed by ${ }^{31} \mathrm{P}$ NMR within the period for the quantitative formation of $\mathbf{1 2 b}-\mathbf{d}$. $^{32}$
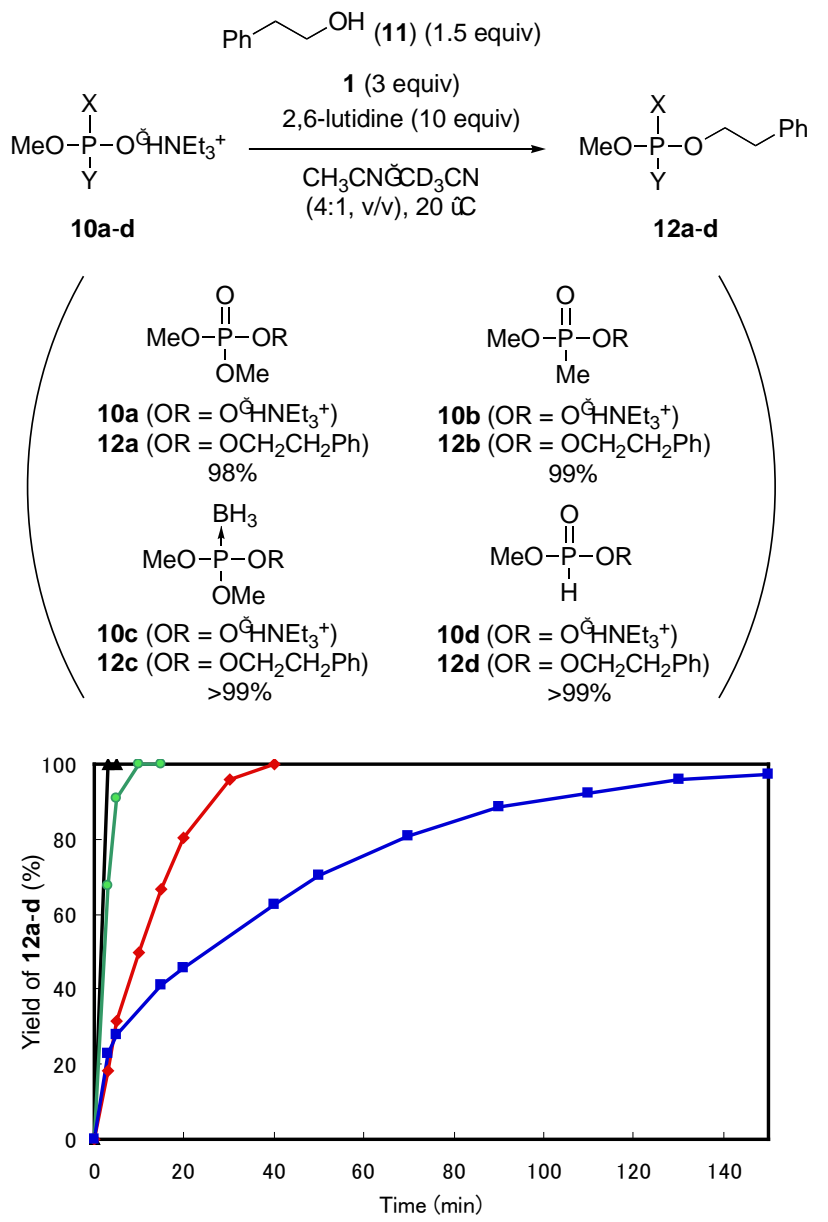

Figure 6. Condensation reactions of 10a-d with $\mathbf{1 1}$ (1.5 equiv) in the presence of $\mathbf{1}$ (3 equiv) in $\mathrm{CH}_{3} \mathrm{CN}-\mathrm{CD}_{3} \mathrm{CN}(4: 1, \mathrm{v} / \mathrm{v})$ at $20{ }^{\circ} \mathrm{C} . \mathbf{\square}, \mathbf{1 0 a} ; \mathbf{1 0 b} ; \bullet, \mathbf{1 0 c} \boldsymbol{\Delta}, \mathbf{1 0 d}$.

\section{Conclusion}

MNTP has proven to be a powerful condensing reagent, which mediated the rapid formation of various phosphate and phosphonate esters. Such versatility and enhanced activity of MNTP would reduce the problem of slow and inefficient reactions in the phosphorylation and phosphonylation of alcohols mediated by conventional condensing reagents and make these methods comparable to the phosphitylation by the phosphoramidite method. MNTP and its simpler counterpart PyNTP were found to be good alternatives to the 
phosphoramidite method, especially for the synthesis of various functionalized phosphate derivatives, which are difficult to be synthesized by the phosphoramidite method. In addition to the synthesis of phosphate derivatives, the new phosphonium-type condensing reagents presented in this paper may also be useful for the rapid assembly of polypeptides as well as carboxylic acid esters, considering the wide-use of phosphonium-type condensing reagents for this purpose.

\section{Experimental}

\subsection{General Information}

${ }^{1} \mathrm{H}$ NMR spectra were obtained at $300 \mathrm{MHz}$ with tetramethylsilane (TMS) as an internal standard in $\mathrm{CDCl}_{3}$ or $\mathrm{CD}_{3} \mathrm{CN} .{ }^{13} \mathrm{C}$ NMR spectra were recorded at $75 \mathrm{MHz}$ with $\mathrm{CDCl}_{3}$ as an internal standard $\left(\delta\right.$ 77.0) in $\mathrm{CDCl}_{3}$, or with $\mathrm{CD}_{3} \mathrm{CN}$ as an internal standard $(\delta$ 117.8) in $\mathrm{CD}_{3} \mathrm{CN}$. ${ }^{31} \mathrm{P}$ NMR spectra were obtained at $121 \mathrm{MHz}$ with $85 \% \mathrm{H}_{3} \mathrm{PO}_{4}$ as an external standard in $\mathrm{CDCl}_{3}$ or $\mathrm{CD}_{3} \mathrm{CN}$. Melting points were uncorrected. Silica gel column chromatography was carried out using silica gel 60N (63-210 $\mu \mathrm{m})$. Organic solvents were purified and dried by appropriate procedures. Isolated phosphate and phosphonate derivatives (12a-c) were determined to be $>95 \%$ pure by ${ }^{1} \mathrm{H},{ }^{13} \mathrm{C}$, and ${ }^{31} \mathrm{P}$ NMR spectroscopies.

\subsection{Ab Initio Calculations}

$A b$ initio molecular orbital calculations were carried out using the Gaussian $03^{35}$ and Spartan ' $04{ }^{36}$ programs on a Dell Precision 650 workstation. Geometry optimizations were carried out at the HF/6-31G* level.

\subsection{1,3-Dimethyl-2-(3-nitro-1,2,4-triazol-1-yl)-2-pyrrolidin-1-yl-1,3,2-}

\section{diazaphospholidinium hexafluorophosphate (MNTP, 1)}

1,3-Dimethyl-2-pyrrolidin-1-yl-1,3,2-diazaphospholidine 8 (14.2 g, $76 \mathrm{mmol}$ ) was added dropwise over 2 h to a stirred solution of 3-nitro-1,2,4-triazole (8.67 g, $76 \mathrm{mmol})$, which was dried by repeated coevaporations with dry pyridine and dry toluene, and dry $\mathrm{CCl}_{4}(29.3 \mathrm{~mL}$, 
$304 \mathrm{mmol})$ in dry $\mathrm{CH}_{2} \mathrm{Cl}_{2}(150 \mathrm{~mL})$ at $-78{ }^{\circ} \mathrm{C}$ under argon. The mixture was then allowed to warm to rt and concentrated to dryness under argon. The residue was dissolved in dry $\mathrm{CH}_{3} \mathrm{CN}$ (75 mL), and a solution of $\mathrm{KPF}_{6}(14.0 \mathrm{~g}, 76 \mathrm{mmol})$ in dry $\mathrm{CH}_{3} \mathrm{CN}(210 \mathrm{~mL})$ was added dropwise over $1 \mathrm{~h}$ to the solution with stirring at rt under argon. The resultant white insoluble solid was removed by suction filtration, and the filtrate was concentrated to dryness. AcOEt (400 mL) was added to the residue, and the insoluble solid was collected by suction filtration, washed with AcOEt (50 mL), and dried under vacuum to afford $\mathbf{1}$ as a colorless crystalline solid (16.9 g, 38 mmol, 50\%). Mp. $175-177{ }^{\circ} \mathrm{C}$ (decomp.). IR (KBr) 3135, 2990, 2898, 1568, 1511, 1280, 1145, 829, 580, $558 \mathrm{~cm}^{-1} .{ }^{1} \mathrm{H}$ NMR (300 MHz, $\left.\mathrm{CD}_{3} \mathrm{CN}\right) \delta 8.85$ (s, $\left.1 \mathrm{H}\right), 3.62-3.33$ (m, 8H), $2.89\left(\mathrm{~J}_{\mathrm{PH}}=11.7 \mathrm{~Hz}, 6 \mathrm{H}\right), 2.06(\mathrm{~m}, 4 \mathrm{H}) .{ }^{13} \mathrm{C} \mathrm{NMR}\left(75 \mathrm{MHz}, \mathrm{CD}_{3} \mathrm{CN}\right) \delta 166.2,153.1$ $\left(d, J_{P C}=7.5 \mathrm{~Hz}\right), 49.6,47.5\left(d, J_{P C}=15.0 \mathrm{~Hz}\right), 31.6\left(d, J_{P C}=4.5 \mathrm{~Hz}\right), 27.0\left(d, J_{P C}=9.0 \mathrm{~Hz}\right)$.

${ }^{31} \mathrm{P}$ NMR (121 MHz, CD $\left.\mathrm{CN}\right) \delta$ 25.0, -144.9 (septet, $\mathrm{J}_{\mathrm{PF}}=701.8 \mathrm{~Hz}$ ). Anal. Calcd for $\mathrm{C}_{10} \mathrm{H}_{19} \mathrm{~F}_{6} \mathrm{~N}_{7} \mathrm{O}_{2} \mathrm{P}_{2}$ : C, 26.98; H, 4.30; N, 22.02. Found: C, 26.77; H, 4.40; N, 21.87.

\subsection{3-Nitro-1,2,4-triazol-1-yl-tris(pyrrolidin-1-yl)phosphonium hexafluorophosphate (PyNTP) 2}

To powdery $\mathrm{NaH}$ (0.254 g, $10.5 \mathrm{mmol})$, prepared from $\mathrm{NaH}$ dispersion in mineral oil prior to use, was added a solution of 3-nitro-1,2,4-triazole (1.14 g, $10 \mathrm{mmol})$, which was dried by repeated coevaporations with dry pyridine and dry toluene, in dry THF (40 mL) at rt under argon. The mixture was then added a solution of PyClop (9) (4.22 g, $10 \mathrm{mmol}$ ) in dry THF (10 mL) at rt, and the mixture was stirred for $2 \mathrm{~h}$. The insoluble solid was filtered off and thoroughly washed with dry $\mathrm{CH}_{2} \mathrm{Cl}_{2}$ (ca. $50 \mathrm{~mL}$ ). The combined filtrate was concentrated under reduced pressure to some extent (ca. $20 \mathrm{~mL}$ ) and cooled to $0{ }^{\circ} \mathrm{C}$. The resultant precipitate was collected by suction filtration, washed with a small amount of THF, and dried under vacuum to afford 2 (4.19 g, $8.4 \mathrm{mmol}, 84 \%)$ as a colorless crystals. Mp. $161-163{ }^{\circ} \mathrm{C}$ (decomp.). IR (KBr) 3118, 2984, 2880, 1566, 1510, 1285, 1143, 854, 590, $557 \mathrm{~cm}^{-1} .{ }^{1} \mathrm{H}$ NMR (300 MHz, CD $\mathrm{CN}_{3} \mathrm{C} 8.79(\mathrm{~s}, 1 \mathrm{H}), 3.40(\mathrm{~m}, 12 \mathrm{H}), 2.03(\mathrm{~m}, 12 \mathrm{H}) .{ }^{13} \mathrm{C}$ NMR $(75 \mathrm{MHz}$, 
$\left.\mathrm{CD}_{3} \mathrm{CN}\right) \delta 165.5,151.7\left(\mathrm{~d}, \mathrm{~J}_{\mathrm{PC}}=8.3 \mathrm{~Hz}\right), 49.0\left(\mathrm{~d}, \mathrm{~J}_{\mathrm{PC}}=4.9 \mathrm{~Hz}\right), 26.5\left(\mathrm{~d}, \mathrm{~J}_{\mathrm{PC}}=9.2 \mathrm{~Hz}\right) .{ }^{31} \mathrm{P}$ NMR (121 MHz, $\left.\mathrm{CD}_{3} \mathrm{CN}\right) \delta 19.3,-142.5$ (septet, $\mathrm{J}_{\mathrm{PF}}=698.8 \mathrm{~Hz}$ ). Anal. Calcd for $\mathrm{C}_{14} \mathrm{H}_{25} \mathrm{~F}_{6} \mathrm{~N}_{7} \mathrm{O}_{2} \mathrm{P}_{2}$ : C, 33.67; H, 5.05; N, 19.64. Found: C, 33.76; H, 5.03; N, 19.58.

\section{5. ${ }^{31} \mathrm{P}$ NMR monitoring of the condensation reactions of dimethyl phosphate or its analogs (10a-d) with 2-phenylethanol 11 in the presence of the phosphonium-type condensing reagents}

$150 \mu \mathrm{mol}$ of $\mathbf{1}$, 2, or $\mathbf{3}$ was placed in an NMR sample tube and dried under vacuum over $\mathrm{P}_{2} \mathrm{O}_{5}$. Dry $\mathrm{CD}_{3} \mathrm{CN}(100 \mu \mathrm{L})$, an anhydrous $\mathrm{CH}_{3} \mathrm{CN}$ solution of triethylammonium dimethyl phosphate (10a) or one of its analogs (10b-d) $(50 \mu \mathrm{mol})$, which was dried by repeated coevaporations with dry $\mathrm{CH}_{3} \mathrm{CN}(400 \mu \mathrm{L})$, dry 2-phenylethanol (11) $(9.0 \mu \mathrm{L}, 75 \mu \mathrm{mol})$, and distilled 2,6-lutidine $(58.2 \mu \mathrm{L}, 500 \mu \mathrm{mol})$ were added. The sample tube was then sealed, shaken to dissolve the condensing reagent. After $1.5 \mathrm{~min}$, the ${ }^{31} \mathrm{P}$ NMR data accumulation was started. Each accumulation was carried out over 1.5 min at every time-point of 3, 5, 15, 20, 40, 50, 70, 90, 110, 130, and 150 min (Figures 3 and 6).

\subsection{Dimethyl 2-phenylethyl phosphate 12a}

After the ${ }^{31} \mathrm{P}$ NMR experiment, the reaction mixture was diluted with $\mathrm{CH}_{2} \mathrm{Cl}_{2}(3 \mathrm{~mL})$ and washed with a $1 \mathrm{M} \mathrm{HCl}$ aqueous solution $(3 \times 3 \mathrm{~mL})$. The combined aqueous layers were back-extracted with $\mathrm{CH}_{2} \mathrm{Cl}_{2}(3 \mathrm{~mL})$, and the combined organic layers were washed with a saturated $\mathrm{NaCl}$ aqueous solution $(2 \times 3 \mathrm{~mL})$. The combined aqueous layers were back-extracted with $\mathrm{CH}_{2} \mathrm{Cl}_{2}(3 \mathrm{~mL})$, and the combined organic layers were dried over $\mathrm{Na}_{2} \mathrm{SO}_{4}$, filtered, and concentrated to dryness. The residue was purified by silica gel column chromatography [hexane/ethyl acetate (1/1, v/v)] to afford 12a (11.3 mg, $49 \mu \mathrm{mol}, 98 \%)$ as a colorless oil. ${ }^{1} \mathrm{H},{ }^{13} \mathrm{C}$, and ${ }^{31} \mathrm{P}$ NMR spectra were identical to those reported in the literature. ${ }^{37}$

\subsection{Methyl 2-phenylethyl methylphosphonate 12b}

After the ${ }^{31} \mathrm{P}$ NMR experiment, the reaction mixture was diluted with $\mathrm{CH}_{2} \mathrm{Cl}_{2}(3 \mathrm{~mL})$, washed with $0.2 \mathrm{M}$ phosphate buffer $(\mathrm{pH} 7)(3 \times 3 \mathrm{~mL})$. The combined aqueous layers were 
back-extracted with $\mathrm{CH}_{2} \mathrm{Cl}_{2}(3 \mathrm{~mL})$, and the combined organic layers were dried over $\mathrm{Na}_{2} \mathrm{SO}_{4}$, filtered, and concentrated to dryness. The residue was purified by silica gel column chromatography [hexane/ethyl acetate (1/1, v/v)] to afford 12b (10.6 mg, $49 \mu \mathrm{mol}, 99 \%)$ as a colorless oil. IR (film) 3444, 2956, 1645, 1497, 1455, 1313, 1231, 1016, 912, 818, $701 \mathrm{~cm}^{-1}$.

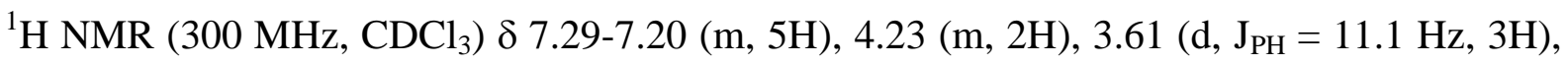
$2.98(\mathrm{t}, \mathrm{J}=6.9 \mathrm{~Hz}, 2 \mathrm{H}), 1.38\left(\mathrm{~d}, \mathrm{~J}_{\mathrm{PH}}=17.4 \mathrm{~Hz}, 3 \mathrm{H}\right) .{ }^{13} \mathrm{C} \mathrm{NMR}\left(75 \mathrm{MHz}, \mathrm{CDCl}_{3}\right) \delta 137.2$, 128.9, 128.4, 126.6, $66.1\left(\mathrm{~d}, \mathrm{~J}_{\mathrm{PC}}=6.3 \mathrm{~Hz}\right), 37.1\left(\mathrm{~d}, \mathrm{~J}_{\mathrm{PC}}=6.3 \mathrm{~Hz}\right), 11.4$, 9.5. ${ }^{31} \mathrm{P}$ NMR (121 $\left.\mathrm{MHz}, \mathrm{CDCl}_{3}\right) \delta$ 33.0. FAB-HRMS: $\mathrm{m} / \mathrm{z}$ calcd for $\mathrm{C}_{10} \mathrm{H}_{15} \mathrm{O}_{3} \mathrm{P}\left(\mathrm{M}^{+}\right)$214.0759, found 214.0752.

\subsection{Dimethyl 2-phenylethyl boranophosphate 12c}

After the ${ }^{31} \mathrm{P}$ NMR experiment, the reaction mixture was diluted with $\mathrm{CH}_{2} \mathrm{Cl}_{2}(3 \mathrm{~mL})$, washed with $0.2 \mathrm{M}$ phosphate buffer $(\mathrm{pH} 7)(3 \times 3 \mathrm{~mL})$. The combined aqueous layers were back-extracted with $\mathrm{CH}_{2} \mathrm{Cl}_{2}$ (3 mL), and the combined organic layers were dried over $\mathrm{Na}_{2} \mathrm{SO}_{4}$, filtered, and concentrated to dryness. The residue was purified by silica gel column chromatography [hexane/ethyl acetate (4/1, v/v)] to afford 12c (11.4 mg, $50 \mu \mathrm{mol}$, quant) as a colorless oil. IR (film) 2955, 2396, 1455, 1260, 1028, 798, $700 \mathrm{~cm}^{-1} .{ }^{1} \mathrm{H}$ NMR (300 MHz, $\left.\mathrm{CDCl}_{3}\right) \delta$ 7.30-7.20 (m, 5H), $4.20(\mathrm{q}, \mathrm{J}=7.1 \mathrm{~Hz}, 2 \mathrm{H}), 3.61\left(\mathrm{~d}, \mathrm{~J}_{\mathrm{PH}}=11.1 \mathrm{~Hz}, 6 \mathrm{H}\right), 2.98(\mathrm{t}, \mathrm{J}=$ 7.1 Hz, 2H), 0.42 (brq, 3H). ${ }^{13} \mathrm{C}$ NMR $\left(75 \mathrm{MHz}, \mathrm{CDCl}_{3}\right) \delta 136.8,128.8,128.3,126.5,67.1$ (d, $\left.\mathrm{J}_{\mathrm{PC}}=3.4 \mathrm{~Hz}\right), 52.9\left(\mathrm{~d}, \mathrm{~J}_{\mathrm{PC}}=3.5 \mathrm{~Hz}\right), 36.8\left(\mathrm{~d}, \mathrm{~J}_{\mathrm{PC}}=5.5 \mathrm{~Hz}\right) .{ }^{31} \mathrm{P}$ NMR $\left(121 \mathrm{MHz}, \mathrm{CDCl}_{3}\right) \delta$ $117.7\left(\mathrm{q}, \mathrm{J}_{\mathrm{PB}}=99.1 \mathrm{~Hz}\right)$. FAB-HRMS: $\mathrm{m} / \mathrm{z}$ calcd for $\mathrm{C}_{10} \mathrm{H}_{18} \mathrm{BO}_{3} \mathrm{P}\left(\mathrm{M}^{+}\right)$228.1089, found 228.1094.

\section{Acknowledgments}

We thank Professor Takashi Yamashita (Tokyo University of Science) for obtaining mass spectra. This work was partially supported by a grant from a Grant-in-Aid for Scientific Research from the Ministry of Education, Culture, Sports, Science and Technology, Japan and by JSPS Research Fellowships for Young Scientists (M.S.). 


\section{Supplementary data}

${ }^{31} \mathrm{P}$ NMR spectra of the reaction mixtures obtained by the reaction of $\mathbf{1 0 a}$ with $\mathbf{1 1}$ in the presence of 2 or $3 ;{ }^{31} \mathrm{P}$ NMR spectra of the reaction mixtures obtained by the reaction of $\mathbf{1 0 b}, \mathbf{c}$, or $\mathbf{d}$ with 11 in the presence of $\mathbf{1} ;{ }^{1} \mathrm{H},{ }^{13} \mathrm{C}$, and ${ }^{31} \mathrm{P}$ NMR spectra of $\mathbf{1}, \mathbf{2}$, and $\mathbf{1 2 b}, \mathbf{c}$. Experimental details for the synthesis of 6-8. Optimized geometries and the orbital energies of the reaction intermediates $\mathbf{1 3 a} \mathbf{3}, \mathbf{b}$.

\section{References and notes}

1. Caruthers, M. H. Chimia 2005, 59, 38-42.

2. Hayakawa, Y. Bull. Chem. Soc. Jpn. 2001, 74, 1547-1565.

3. Potter, B. V. L.; Lampe, D. Angew. Chem. Int. Ed. Engl. 1995, 34, 1933-1972.

4. Watanabe, Y. Selective reactions and total synthesis of inositol phosphates; Rahman, A., Ed. Studies in Natural Products Chemistry Vol. 18 (Stereoselective Synthesis, Part K). Elsevier: Amsterdam, 1996; pp 391-456.

5. Nifantiev, E. E.; Grachev, M. K.; Burmistrov, S. Y. Chem. Rev. 2000, 100, 3755-3799.

6. Beaucage, S. L.; Iyer, R, P. Tetrahedron 1993, 49, 10441-10448.

7. McMurray, J. S.; Coleman IV, D. R.; Wang, W.; Campbell, M. L. Biopolymers 2001, 60, 3-31.

8. Beaucage, S. L.; Caruthers, M. H. Tetrahedron Lett. 1981, 22, 1859-1862.

9. Beaucage, S. L.; Iyer, R, P. Tetrahedron 1992, 48, 2223-2311.

10. Nurminen, E.; Lönnberg, H. J. Phys. Org. Chem. 2004, 17, 1-17.

11. Michalski, J.; Dabkowski, W. Top Curr. Chem. 2004, 232, 93-144.

12. Hayakawa, Y.; Hirose, M.; Hayakawa, M.; Noyori, R. J. Org. Chem. 1995, 60, 925-930.

13. Froehler, B. C.; Ng, P. G.; Matteucci, M. D. Nucleic Acids Res. 1986, 14, 5339-5407.

14. Zhang, J.; Terhorst, T.; Matteucci, M. D. Tetrahedron Lett. 1997, 38, 4957-4960. 
15. Higson, A. P.; Sierzchala, A.; Brummel, H.; Zhao, Z.; Caruthers, M. H. Tetrahedron Lett. 1998, 39, 3899-3902.

16. Sergueeva, Z. A.; Sergueev, D. S.; Shaw, B. R. Nucleosides Nucleotides 2000, 19, 275-282.

17. Wada, T.; Sato, Y.; Honda, F.; Kawahara, S.; Sekine, M. J. Am. Chem. Soc. 1997, 119, $12710-12721$.

18. Wada, T.; Shimizu, M.; Oka, N.; Saigo, K. Tetrahedron Lett. 2002, 43, 4137-4140.

19. Shimizu, M.; Wada, T.; Oka, N.; Saigo, K. J. Org. Chem. 2004, 69, 5261-5268.

20. Castro, B.; Dormoy, J. R. Tetrahedron Lett. 1972, 13, 4747-4750.

21. Coste, J.; Le-Nguyen, D.; Castro, B. Tetrahedron Lett. 1990, 31, 205-208.

22. Coste, J.; Frerot, E.; Jouin, P. J. Org. Chem. 1994, 59, 2437-2446.

23. Han, S.-Y.; Kim, Y.-A. Tetrahedron 2004, 60, 2447-2467.

24. Kehler, J.; Püschl, A.; Dahl, O. Tetrahedron Lett. 1996, 37, 8041-8044.

25. Campagne, J.-M.; Coste, J.; Jouin, P. J. Org. Chem. 1995, 60, 5214-5223.

26. Hashimi, S. A. N.; Adiraj, M.; Kumar, A.; Katti, S. B. Nucleosides Nucleotides 1994, 13, 1059-1067.

27. Molko, D.; Guy, A.; Teoule, R. Nucleosides Nucleotides 1982, 1, 65-80.

28. Reese, C. B.; Tatmas, R. C.; Yau, L. Tetrahedron Lett. 1978, 19, 2727-2730.

29. We synthesized $\mathbf{8}$ in a different way from the original one in the literature. Ramirez, F.; Patwardham, A. V.; Kugler, H. J.; Smith, C. P. J. Am. Chem. Soc. 1967, 89, 6276-6282. For the experimental details, see the Supplementary data.

30. Lit. $\delta$-10.5/CDCl $\mathrm{Cl}_{3}$ Jaszay, Z. M.; Petnehazy, I.; Toke, L. Heteroatom Chem. 2004, 15, 447-450.

31. We consider the pathway in which 12a is generated directly from 14a can be excluded because it is known that the direct nucleophilic attack of a hydroxyl group to this type of pyrophosphates is extremely slow without the assistance of strong bases or nucleophilic 
catalysts. Chandrasegaran, S.; Murakami, A.; Kan, L. J. Org. Chem. 1984, 49, 4951-4957. 32. See the Supplementary data.

33. Marugg, J. E.; Piel, P.; McLaughlin, L. W.; Tromp, M.; Veeneman, G. H.; van der Marel, G. A.; van Boom, J. H. Nucleic Acids Res. 1984, 12, 8639-8651.

34. 2 did not react with alcohols even in the presence of $N, N, N^{\prime}, N^{\prime}$-tetramethyl-1,8-naphthalenediamine.

35. Gaussian 03, Revision B.03, Frisch, M, J.; Trucks, G. W.; Schlegel, H. B.; Scuseria, G. E.; Robb, M. A.; Cheeseman, J. R.; Montgomery, Jr., J. A.; Vreven, T.; Kudin, K. N.; Burant, J. C.; Millam, J. M.; Iyengar, S. S.; Tomasi, J.; Barone, V.; Mennucci, B.; Cossi, M.; Scalmani, G.; Rega, N.; Petersson, G. A.; Nakatsuji, H.; Hada, M.; Ehara, M.; Toyota, K.; Fukuda, R.; Hasegawa, J.; Ishida, M.; Nakajima, T.; Honda, Y.; Kitao, O.; Nakai, H.; Klene, M.; Li, X.; Knox, J. E.; Hratchian, H. P.; Cross, J. B.; Adamo, C.; Jaramillo, J.; Gomperts, R.; Stratmann, R. E.; Yazyev, O.; Austin, A. J.; Cammi, R.; Pomelli, C.; Ochterski, J. W.; Ayala, P. Y.; Morokuma, K.; Voth, G. A.; Salvador, P.; Dannenberg, J. J.; Zakrzewski, V. G.; Dapprich, S.; Daniels, A. D.; Strain, M. C.; Farkas, O.; Malick, D. K.; Rabuck, A. D.; Raghavachari, K.; Foresman, J. B.; Ortiz, J. V.; Cui, Q.; Baboul, A. G.; Clifford, S.; Cioslowski, J.; Stefanov, B. B.; Liu, G.; Liashenko, A.; Piskorz, P.; Komaromi, I.; Martin, R. L.; Fox, D. J.; Keith, T.; Al-Laham, M. A.; Peng, C. Y.; Nanayakkara, A.; Challacombe, M.; Gill, P. M. W.; Johnson, B.; Chen, W.; Wong, M. W.; Gonzalez, C.; Pople, J. A. Gaussian, Inc., Pittsburgh PA, 2003.

36. Spartan'04, Kong, J.; White, C. A.; Krylov, A. I.; Sherrill, C. D.; Adamson, R. D.; Furlani, T. R.; Lee, M. S.; Lee, A. M.; Gwaltney, S. R.; Adams, T. R.; Ochsenfeld, C.; Gilbert, A. T. B.; Kedziora, G. S.; Rassolov, V. A.; Maurice, D. R.; Nair, N.; Shao, Y.; Besley, N. A.; Maslen, P. E.; Dombroski, J. E.; Dachsel, H.; Zhang, W. M.; Korambath, P. P.; Baker, J.; Byrd, E. F. C.; Van Voorhis, T.; Oumi, M.; Hirata, S.; Hsu, C. P.; Ishikawa, N.; Florian, J.; Warshel, A.; Johnson, B. G.; Gill, P. M. W.; Head-Gordon, M.; Pople, J. A. 
Wavefunction, Inc., Irvine, CA, 2004.

37. Oza, V. B.; Corcoran, R. C. J. Org. Chem. 1995, 60, 3680-3684.

\section{Footnotes}

*Corresponding author. Tel/fax: +81-4-7136-3612; email: wada@k.u-tokyo.ac.jp. 